\title{
ANALISIS PENGARUH PENYULUHAN PERKEBUNAN TERHADAP HASIL PANEN PETANI KEBUN DI KAMPUNG SEKRU KABUPATEN FAKFAK
}

\author{
Deisya Maulida Al Hamid \\ Dosen Politeknik Negeri Fakfak
}

\begin{abstract}
Abstrak
Penyuluhan perkebunan sebagai bagian integral pembangunan perkebunan merupakan salah satu upaya pemberdayaan untuk meningkatkan produktivitas, pendapatan dan kesejahteraannya. Untuk itu kegiatan penyuluhan pertanian harus dapat mengakomodasi aspirasi peran aktif melalui pendekatan partisipatif. Idealnya penyuluhan perkebunan akan mendatangkan pengetahuan lebih kepada para petani kebun dalam hal pengelolaan lahan, pemilihan bibit unggul, penanganan hama, serta permasalahan lainnya, yang berimbas pada peningkatan hasil panen. Penyuluhan yang efektif akan membantu para petani kebun memperoleh hasil panen yang lebih optimal. Oleh karena itu penelitian ini dilakukan untuk mengetahui pengaruh pelaksanaan penyuluhan terhadap peningkatan hasil panen pada komoditi unggulan di kampung Sekru, Fakfak.
\end{abstract}

Kata Kunci : penyuluhan, petani kebun, pala, Fakfak 
PENDAHULUAN

Sebagai salah satu kabupaten di Negara yang bercorak agraris, Fakfak memiliki potensi yang sangat besar untuk pengembangan tanaman perkebunan dalam rangka mewujudkan kemakmuran dan kesejahteraan rakyat.

Perkebunan mempunyai peranan penting dan strategis dalam mewujudkan ketahanan pangan nasional, yang berperan penting dalam meningkatkan kemakmuran dan kesejahteraan rakyat. Oleh karena itu Pemerintah mengupayakan untuk meningkatkan hasil panen komoditi perkebunan, bukan hanya kuantitasnya, melainkan disertai peningkatkan kualitas, keamanan, dan kontinuitas produksi dengan tingkat harga yang kompetitif.

Penyuluhan perkebunan sebagai bagian integral pembangunan perkebunan merupakan salah satu upaya pemberdayaan untuk meningkatkan produktivitas, pendapatan dan kesejahteraannya. Untuk itu kegiatan penyuluhan pertanian harus dapat mengakomodasi aspirasi peran aktif melalui pendekatan partisipatif.

Pengembangan pembangunan perkebunan di masa mendatang perlu memberikan perhatian khusus terhadap penyuluhan perkebunan, karena penyuluhan perkebunan merupakan salah satu kegiatan yang strategis dalam upaya pencapaian tujuan pembangunan pertanian. Melalui kegiatan penyuluhan, ditingkatkan kemampuan agar dapat mengelola usaha dengan produktif, efisien dan menguntungkan.

Idealnya penyuluhan perkebunan akan mendatangkan pengetahuan lebih kepada para petani kebun dalam hal pengelolaan lahan, pemilihan bibit unggul, penanganan hama, serta permasalahan lainnya, yang berimbas pada peningkatan hasil panen. Penyuluhan yang efektif akan membantu para petani kebun memperoleh hasil panen yang lebih optimal.

\section{IDENTIFIKASI MASALAH}

1. Daerah Fakfak merupakan daerah yang kaya akan sumber daya alam dan memiliki tanah yang berstruktur bebatuan namun cukup subur. Berbagai peralatan berkebun dan kelengkapannya, seperti pupuk, bibit unggul dan sebaliknya tidak mudah diperoleh di Fakfak dikarenakan keterbatasan transportasi.

2. Fakfak dikenal sebagai daerah penghasil pala, namun kemashyuran pala dari Fakfak belum setara dengan daerah penghasil pala lainnya. Oleh karena itu penyuluhan perkebunan diharapkan dapat meningkatkan pengetahuan petani kebun sehingga mampu menghasilkan kuantitas dan kualitas produksi tanaman perkebunan 
di kabupaten Fakfak, terutama produksi pala yang saat ini menjadi sumber kehidupan bagi cukup banyak petani kebun.

3. Mengenal komoditi unggulan lain yang dihasilkan petani lokal selain pala.

\section{BATASAN MASALAH}

1. Analisis dalam penelitian ini difokuskan pada pengaruh pelaksanaan penyuluhan perkebunan kepada para petani kebun di Kampun Sekru Kabupaten Fakfak untuk meningkatkan kuantitas dan kualitas hasil panennya selama tahun 2015-2017.

2. Analisis pengaruh penyuluhan perkebunan terhadap peningkatan kuantitas dan kualitas hasil panen ini dilakukan dengan berbasis software Statistical Package for the Social Sciences atau Paket Statistik untuk Ilmu Sosial.

\section{TUJUAN PENELITIAN}

Tujuan dari penelitian ini adalah untuk membuktikan seberapa kuat pengaruh pelaksanaan penyuluhan perkebunan terhadap peningkatan kuantitas dan kualitas hasil panen petani kebun di Kampung Sekru Kabupaten Fakfak.

\section{MANFAAT PENELITIAN}

1. Untuk mengetahui dan mengoptimalkan faktor-faktor yang mendukung peningkatan kualitas dan kuantitas panen para petani kebun untuk keanekaragaman komoditi perkebunan di kabupaten Fakfak, sekaligus meningkatkan kesejahteraan para petani.

2. Sebagai bahan evaluasi atas pelaksanaan penyuluhan, khususnya di sektor perkebunan, karena sudah barang tentu idealnya penyuluhan memiliki pengaruh yang signifikan dalam peningkatan kuantitas dan kualitas hasil panen petani kebun.

\section{LANDASAN TEORI}

Guna membantu usaha tani, pemerintah membantu dengan memberikan penyuluhan pertanian yang dilakukan oleh para tenaga dinas penyuluhan pertanian kepada para petani di berbagai tempat. Menurut A.W Van Den Ban (1998: 23), penyuluhan memiliki beberapa arti, jika ditinjau dari bahasa Belanda berasal dari kata Voorlochting yang berarti memberi penerangan untuk menolong seseorang menemukan jalannya, sedangkan Malaysia yang dipengaruhi bahasa Inggris menggunakan kata perkembangan. Bahasa Inggris dan Jerman masing-masing menggunakan istilah sebagai pemberian saran atau beratung yang berarti seorang pakar dapat memberikan petunjuk kepada seseorang, tetapi seseorang tersebut yang berhak untuk menentukan pilihannya. 
Dalam bahasa Jerman juga menggunakan kata Aufklarung (pencerahan) yang menekankan pentingnya mempelajari nilai-nilai yang mendasari hidup sehat dan pentingnya mengetahui arah langkah kita. Kata lain yang juga lazim dipakai yaitu Erziehung yang mirip artinya dengan pendidikan di Amerika Serikat, yang menekankan tujuan penyuluhan pertanian untuk mengajarkan seseorang sehingga dapat memecahkan sendiri masalahnya.

Dalam bahasa Austria dikenal istilah Forderung yang berarti menggiring seseorang kearah yang diinginkan. Dalam bahasa Perancis menggunakan istilah Vulgarisation yang menekankan pentingnya menyederhanakan pesan bagi orang awam. Capacitacion dalam bahasa Spanyol menunjukkan adanya keinginan untuk meningkatkan kemampuan manusia yang dapat diartikan dengan pelatihan.

Menurut Kamus Besar Bahasa Indonesia, kata penyuluhan berasal dari kata suluh, yang berarti barang yang dipakai untuk media penerangan. Sedangkan penyuluh adalah orang yang bertugas memberikan penerangan atau petunjuk jalan. Oleh sebab itu, arti dari kata penyuluhan adalah suatu proses atau metode yang dilakukan oleh seorang penyuluh untuk memberikan penerangan atau informasi kepada orang lain dari semula yang tidak tau menjadi tahu.
Penyuluhan merupakan sistem pendidikan di luar sekolah.dimana mereka belajar sambil berbuat untuk menjadi tahu, mau, dan mampu atau bisa menyelesaikan diri sendiri masalah yang dihadapi menguntungkan dan memuaskan. Jadi penyuluhan adalah sesuatu bentuk pendidikan yang cara bahan dan saranannya di sesuaikan dengan keadaan, kebutuhan, dan kepentingan sasaran. Karena yang sifatnya demikian, penyuluhan disebut pendidikan non formal (Wiriaatmadja, 1973).

Panen adalah pemungutan (pemetikan) hasil sawah atau kebun. Berdasarkan bagian dari komoditi atau tanaman yang dipanen, metode pemanenan dapat dibagi menjadi dua bagian yaitu:

1. Pemanenan Keseluruhan

Yaitu mengambil seluruh bagian tubuh individu suatu tanaman sehingga individu tersebut tidak lagi hidup.

2. Pemanenan Sebagian

Yaitu yang dipanen bukanlah seluruh bagian tanamannya, melainkan bagian yang dimanfaatkan. Umumnya tanaman perkebunan hanya dipanen sebagian.

Keadaan topografi areal kampung Sekru :

1. Posisi dalam fisiografi pada kaki lereng dengan kemiringan

- Datar $(<5 \%): 95 \%$ 
- Miringan (5-10\%): $3 \%$

- Berombak $(10-15 \%): 1 \%$

- Berbukit $(15-30 \%) \quad: 1 \%$

2. Jenis tanah yang dominan :

$\begin{array}{ll}\text { Kambisol } & : 52.80 \% \\ \text { Litosol } & : 23.15 \% \\ \text { Mediteran } & : 3.39 \% \\ \text { Tanah Campuran } & : 11.60 \%\end{array}$

3. Warna Tanah : Very dark brown yelowis brown

4. Tekstur tanah : Lempung Lempung berliat - Liat berlempung

5. Struktur tanah : Gumpal - gumpal bersudut

Halus - sedang, 5 $10 \mathrm{~mm}$

6. Konsistensi : Lembab; gembur agak teguh

Basah; teguh

7. $\mathrm{pH}$ Tanah : 6,5 s/d 7 (netral)

8. Kondisi BO : Sedang-Banyak

9. Kondisi Kapur : Sedang

10. Waktu dan rata-rata curah hujan bulanan di lokasi (menurut BKMG dalam Statistik Fakfak, BPS, 2016)

- Musim Hujan

Bulan Juni s.d. Agustus

- Musim Kemarau

Bulan September s.d. November

- Rata-rata curah hujan

Bulan basah $22 \mathrm{~mm} / \mathrm{bulan}$

Bulan kering $18 \mathrm{~mm} / \mathrm{bulan}$
- Curah HujanTertinggi : 169 mm (bulan Juni)

- Curah HujanTerendah 150, $4 \mathrm{~mm}$ (bulan Maret)

11. Ketinggian tempat : 4 mdpl

Komoditi Unggulan para Petani Kebun di kampung Sekru, Fakfak :

1. Pala (Myristica Fragrans Houtt)

Sampai saat ini Indonesia termasuk salah satu negara produsen dan pengekspor biji dan fuli pala terbesar dunia. Pasar utama tujuan ekspor pala Indonesia (dari sisi volume) adalah Vietnam, Amerika Serikat, Belanda, Jerman, dan Italia. Produksi pala Indoensaia pada tahun 2011 mencapai 15.793 ton, yang dihasilkan dari luas areal produksi 118.345 hektar, dimana 99\%-nya adalah hasil produksi perkebunan rakyat dan provinsi Papua Barat menyumbang lebih kurang $11 \%$ dari jumlah tersebut.

Fakfak merupakan salah satu daerah penghasil pala utama di provinsi Papua Barat, selain kabupaten Kaimana. Hampir 80\% lahan di kabupaten Fakfak ditumbuhi oleh tanaman pala, termasuk di kampung Sekru. Luas tanaman Pala di kabupaten Fakfak mencapai 6.071 hektar (58\% dari total dari total luar area penanaman pala di 
provinsi Papua Barat dan memiliki potensi produksi mencapai 1.884 ton.

Pelaku utama dalam rantai nilai komoditas pala adalah petani dan pedagang pala. Jumlah petani yang cukup banyak menjadi penentu dalam kontinuitas pasokan serta kualitas pala, namun hingga saat ini posisi petani masih sangat lemah yang mengakibatkan pendapatan yang diterima petani relatif rendah, dikarenakan berbagai faktor pada masa produksi.

Secara umum, tanaman pala di kabupaten Fakfak sebenarnya belum bisa disebut sebagai tanaman perkebunan, karena pada kenyataannya mayoritas tanaman pala di kabupaten ini merupakan hasil perkembangbiakan alami yang tumbuh di hutan-hutan ulayat dan warisan turun temurun dari nenek moyang terdahulu. Namun tak dapat dipungkiri, pengetahuan petani tentang teknik budidaya intensif masih sangat minim, dengan pola panen yang tidak sesuai (panen muda). Itulah sebabnya penguatan teknik budidaya melalui penyuluhan kepada para petani menjadi isu utama mengingat perannya yang sangat penting untuk mendukung program-program pengembangan dan peningkatan kualitas serta kuantitas pala di masa depan.
Tanaman pala membutuhkan iklim yang panas dengan curah hujan yang tinggi dan agak merata/tidak banyak berubah sepanjang tahun. Suhu udara lingkungan 20-30 derajat $\mathrm{C}$ sedangkan, curah hujan terbagi secara teratur sepanjang tahun. Tanaman pala tergolong jenis tanaman yang tahan terhadap musim kering selama beberapa bulan. Tanaman ini membutuhkan tanah yang gembur, subur dan sangat cocok pada tanah vulkasnis yang mempunyai pembuangan air yang baik. Tanaman pala tumbuh baik di tanah yang bertekstur pasir sampai lempung dengan kandungan bahan organis yang tinggi. Sedangkan $\mathrm{pH}$ tanah yang cocok untuk tanaman pala adalah 5,56,5. Tanaman ini peka terhadap gangguan air, maka untuk tanaman ini harus memiliki saluran drainase yang baik. Pada tanah-tanah yang miring seperti pada lereng pegunungan, agar tanah tidak mengalami erosi sehingga tingkat kesuburannya berkurang, maka perlu dibuat teras-teras melintang lereng. Tanaman pala dapat tumbuh baik di daerah yang mempunyai ketinggian 500-700 m dpl. Sedangkan pada ketinggian di atas $700 \mathrm{~m}$, produksitivitas tanaman akan rendah. Umumnya pohon pala mulai berbuah pada umur 7 tahun dan pada umur 10 
tahun telah berproduksi secara menguntungkan. Produksi pada akan terus meningkat dan pada umur 25 tahun mencapai produksi tertinggi. Pohon pala terus berproduksi sampai umur 60-70 tahun. Buah pala dapat dipetik (dipanen) setelah cukup masak (tua), yakni yaitu sekitar 6-7 bulan sejak mulai bunga dengan tanda-tanda buah pala yang sudah masak adalah jika sebagian dari buah tersebut tersebut murai merekah (membelah) melalui alur belahnya dan terlihat bijinya yang diselaputi fuli warna merah. Jika buah yang sudah mulai merekah dibiarkan tetap dipohon selama 2-3 hari, maka pembelahan buah menjadi sempurna (buah berbelah dua) dan bijinya akan jatuh di tanah. Petani mengenal 3 macam waktu panen tiap tahun, yaitu: (1) panen raya/besar (pertengahan musim hujan); panen lebih sedikit (awal musim hujan) dan panen kecil (akhir musim hujan). Panen buah pala pada permulaan musim hujan memberikan hasil paling baik (berkualitas tinggi) dan bunga pala (fuli) yang paling tebal.

\section{Pisang Cavendish (Musa Spp)}

Pisang cavendish adalah jenis pisang yang paling populer di Indonesia dan di dunia umumnya. Nama lain dari pisang cavendish adalah pisang ambon putih. Pisang cavendish dapat tumbuh di iklim tropis (tropical fruits). Meskipun jenis pisang ini dapat tumbuh di Indonesia bukan berarti pisang ini berasal dari Indonesia, akan tetapi berasal dari Amerika. Permintaan pasar mengenai pisang ini terus meningkat, sehingga harus dipenuhi dengan impor. Ciri fisik dari pohon pisang cavendish adalah memiliki tinggi batang 2,5 - 3 m. Dengan warna batang hijau kehitaman. Dan warna pada daun adalah hijau tua. Setiap tandan memiliki panjang sekitar $60-100 \mathrm{~cm}$ dengan berat mulai dari $15-30 \mathrm{~kg}$. Setiap tandan pisang cavendish terdiri dari $8-13$ sisir dan setiap sisir terdiri dari $12-22$ buah pisang. Pisang cavendish memiliki rasa yang manis dan lembut namun sedikit asam. Kulit pisang cavendish berwarna hijau kekuningan dan sedikit tebal. Apabila telah matang maka akan berwarna kuning mulus.

Faktor terpenting dalam pertumbuhan pisang cavendish adalah terletak pada suhu. Suhu optimal untuk pertumbuhan pisang adalah sekiat $27^{\circ} \mathrm{C}$ dan suhu maksimalnya $38^{\circ} \mathrm{C}$. Pisang cavendish dapat tumbuh di daerah dengan iklim tropis dan subtropis, misalnya negara Asia Tenggara dan beberapa negara Asia Utara. Namun pisang cavendish tidak 
akan bisa tumbuh di daerah pada ketinggian diatas 1600 mdpl.

Pisang cavendish akan tumbuh secara optimal jika ditanam di daerah dengan tingkat sinar matahari cukup stabil. Apabila sinar matahari yang mengenai pisang cavendish terlalu berlebihan maka akan merusak batang pohon dan menyebabkan pohon mati. Pohon pisang ini sangat sensitif terhadap angin kencang. Karena bisa menyebabkan daun rusak serta robek dan pada akhirnya dapat merobohkan pohon. Curah hujan yang dibutuhkan tanaman cavendish adalah $200-220$ mm dengan kelembapan tanah tidak kurang dari $60 \%-70 \%$. Tanah yang paling baik untuk menaman pohon cavendish adalah tanah liat dan gembur serta memiliki aerasi yang baik dengan tingkat konsentrasi $\mathrm{pH}$ antara 4,5 - 7,5.

\section{HASIL DAN PEMBAHASAN}

Pelaksanaan penyuluhan kepada para petani di kampung Sekru selama tahun 2016 sampai dengan 2017 terbilang relatif konstan frekuensinya yaitu sebanyak dua hingga tiga kali penyuluhan dalam setiap minggu. Sedangkan pada 2015 hanya dilakukan tiga sampai empat kali dalam sebulan. Penyuluhan ini meliputi pengenalan komoditi unggulan, pengetahuan dan teknik budidaya, sampai dengan pendampingan masa panen.
Data Pelaksanaan Penyuluhan

\begin{tabular}{|c|c|c|}
\hline Tahun & Bulan & $\begin{array}{c}\text { Frekuensi (kali } \\
\text { per bulan) }\end{array}$ \\
\hline \multirow{13}{*}{2015} & Januari & 4 \\
\hline & Februari & 3 \\
\hline & Maret & 8 \\
\hline & April & 8 \\
\hline & Mei & 8 \\
\hline & Juni & 4 \\
\hline & Juli & 3 \\
\hline & Agustus & 4 \\
\hline & September & 8 \\
\hline & Oktober & 4 \\
\hline & November & 8 \\
\hline & Desember & 3 \\
\hline & Jumlah & 65 kali \\
\hline \multirow{13}{*}{2016} & Januari & 8 \\
\hline & Februari & 8 \\
\hline & Maret & 8 \\
\hline & April & 8 \\
\hline & Mei & 12 \\
\hline & Juni & 8 \\
\hline & Juli & 8 \\
\hline & Agustus & 12 \\
\hline & September & 12 \\
\hline & Oktober & 12 \\
\hline & November & 12 \\
\hline & Desember & 12 \\
\hline & Jumlah & 116 kali \\
\hline \multirow{11}{*}{2017} & Januari & 12 \\
\hline & Februari & 12 \\
\hline & Maret & 12 \\
\hline & April & 12 \\
\hline & Mei & 12 \\
\hline & Juni & 12 \\
\hline & Juli & 12 \\
\hline & Agustus & 12 \\
\hline & September & 12 \\
\hline & Oktober & 12 \\
\hline & Jumlah & 120 kali \\
\hline
\end{tabular}

Sesuai dengan lingkup penelitian, maka data panen dalam penelitian ini hanyalah panen yang dilakukan petani selama kurun waktu tahun 2015 sampai dengan 2017 
pada dua komoditi unggulan yaitu Pala dan pisang Cavendish.

Data panen untuk dua komoditi unggulan adalah sebagai berikut :

Data Pelaksanaan Penyuluhan

\begin{tabular}{|c|c|c|}
\hline \multirow{2}{*}{ Tahun } & \multicolumn{2}{|c|}{ Jenis Komoditi (dalam kg) } \\
\cline { 2 - 3 } & Pala & $\begin{array}{c}\text { Pisang } \\
\text { Cavendish }\end{array}$ \\
\hline 2015 & 207.540 & 770 \\
\hline 2016 & 201.050 & 1.260 \\
\hline 2017 & 224.280 & 2.140 \\
\hline
\end{tabular}

Sumber : Data Dinas Perkebunan

Fakfak

\section{Analisis Regresi}

Guna membuktikan hipotesis yang telah dikemukakan, dilakukan analisis dari data yang telah diperoleh, yaitu data tentang penyuluhan, motivasi, disiplin kerja petani, dan produktivitas kerja petani. Alat analisis yang digunakan dalam penelitian ini adalah analisis regresi linier berganda dengan variabel dependen produktivitas kerja petani dan variabel independen sebanyak tiga variabel, yaitu penyuluhan, motivasi dan disiplin kerja petani. Dengan menggunakan bantuan program SPSS versi 22.0 for windows diperoleh persamaan garis regresi sebagai berikut :

$Y=-1,428+0,061 X 1+0,011 X 2+0,982 X 3$

Interpretasi dari persamaan garis regresi tersebut adalah :

a : $-1,428$ artinya jika penyuluhan (X1), motivasi (X2) dan disiplin kerja petani (X3) sama dengan nol, maka produktivitas kerja petani negative b1 : 0,061 artinya variabel penyuluhan (X1) berpengaruh positif terhadap produktivitas kerja petani (Y), dengan asumsi variabel motivasi (X2) dan variabel disiplin kerja (X3) dianggap tetap.

Hal tersebut dapat dijelaskan bahwa petugas penyuluh pertanian di lapangan sangat diperlukan dalam meningkatkan produktivitas kerja petani di mana hal tersebut akan meningkatkan taraf hidup para petani guna mendorong pertumbuhan ekonomi dan pembangunan di daerah dan juga tercapainya swasembada pangan.

b2 : 0,011, artinya variabel motivasi (X2) berpengaruh positif terhadap produktivitas kerja petani (Y), dengan asumsi variabel penyuluhan (X1) dan variabel disiplin kerja (X3) dianggap tetap. Hal tersebut dapat dijelaskan bahwa motivasi kerja sangat diperlukan dalam meningkatkan produktivitas kerja petani di mana hal tersebut akan meningkatkan semangat kerja petani dan akan bekerja tidak memgenal lelah walau harga pupuk mahal tetapi harga panen menurun, hal ini hanya bisa didorong dengan memberikan motivasi yang tinggi terhadap para petani. 
b3 : 0,982, artinya variabel disiplin kerja (X3) berpengaruh positif terhadap produktivitas kerja petani (Y), dengan asumsi variabel penyuluhan (X1) dan variabel motivasi (X2) dianggap tetap. Selain penyuluhan dan motivasi kerja yang tinggi sangat diperlukan dalam meningkatkan produktivitas kerja petani, disiplin petani dalam bekerja juga sangat penting dalam mengelola usahanya agar hasil yang dicapai dapat meningkat sesuai diharapkan.

\section{Uji Hipotesis}

Analisis regresi linier berganda, yaitu suatu alat uji untuk menganalisis pengaruh nyata dari variabel independen terhadap variabel dependen dengan rumus sebagai berikut:

$$
\mathrm{Y}=\alpha+\mathrm{b} 1 \times 1+\mathrm{b} 2 \times 2+\mathrm{b} 3 \times 3+\mathrm{e}
$$

Di mana:

$\begin{array}{ll}\mathrm{Y} & : \text { Produktivitas kerja } \\ \mathrm{X} 1 & : \text { Penyuluhan } \\ \mathrm{a} & : \text { Konstanta/ intercept } \\ \mathrm{b} & : \text { Koefisiensi regresi } \\ \mathrm{X} 1 & : \text { Penyuluhan } \\ \mathrm{X} 2 & : \text { Motivasi } \\ \mathrm{X} 3 & : \text { Disiplin Kerja } \\ \varepsilon & : \text { standard error }\end{array}$

a. Uji t (Uji signifikansi regresi secara parsial)

Uji t merupakan pengujian variabel penjelas secara individu yang dilakukan untuk mengetahui apakah masing-masing variabel independen berpengaruh secara signifikan terhadap variabel dependen dengan menganggap variabel independen lainnya konstan. Jika hasil uji koefisien regresi parsial (Uji t) menunjukkan bahwa secara individual variabel Penyuluhan, Motivasi dan Disiplin Kerja nilai tingkat probabilitasnya lebih kecil dari 0,05 , berarti terdapat pengaruh yang signifikan, dan sebaliknya jika nilai tingkat probabilitasnya lebih besar dari 0,05 , berarti tidak terdapat pengaruh yang signifikan.

b. Uji F (Uji signifikansi regresi simultan)

Uji $F$ digunakan untuk menguji pengaruh variabel bebas secara simultan atau bersama-sama terhadap variabel terikat. Jika hasil uji $\mathrm{F}$ menunjukkan bahwa secara simultan atau bersamasama variabel Penyuluhan, Motivasi dan Disiplin Kerja nilai tingkat probabilitasnya lebih kecil dari 0,05, berarti terdapat pengaruh yang signifikan, dan sebaliknya jika nilai tingkat probabilitasnya lebih besar dari 0,05, berarti tidak terdapat pengaruh yang signifikan.

c. Uji R2 (Uji Koefisien Determinasi) Uji R2 atau Koefisien Determinasi pada intinya adalah untuk mengukur 
seberapa kuat kemampuan model penelitian menerangkan variasi variabel dependen pada nilai koefisien determinasi antara 0 (nol) sampai dengan 1 (satu). Nilai koefisien determinasi yang kecil berarti menunjukkan kemampuan variabelvariabel independen dalam menjelaskan variabel dependen sangat terbatas.

\section{Hasil Yang Diperoleh}

a. Validitas dan Reliabilitas

- Instrumen Hasil uji validitas instrumen variabel Produktivitas Kerja Petani (Y) valid karena $\mathrm{p}$ value $<0,05$, sehingga data tersebut dapat digunakan semua untuk keperluan analisis penelitian.

- Hasil uji validitas instrumen variabel $\mathrm{X} 1 \quad$ Variabel Penyuluhan) valid karena $\mathrm{p}$ value $<0,05$, sehingga data tersebut dapat digunakan semua untuk keperluan analisis penelitian.

- Hasil uji validitas instrumen variabel X2 (Variabel Motivasi) valid karena $\mathrm{p}$ value $<0,05$, sehingga data tersebut dapat digunakan semua untuk keperluan analisis penelitian.

- Hasil uji validitas instrumen variabel X3 (Variabel Disiplin
Kerja) valid karena $\mathrm{p}$ value $<0,05$, sehingga data tersebut dapat digunakan semua untuk keperluan analisis penelitian.

Berdasarkan hasil uji reliabilitas tersebut dapat diketahui bahwa semua item pertanyaan mengenai variable Penyuluhan (X1), Motivasi (X2), Disiplin Kerja (X3) dan Produktivitas Kerja (Y) menunjukkan nilai Cronbach Alpha >0,60, maka item dinyatakan reliabel.

\section{Uji Asumsi Klasik}

- Uji Multikolinieritas

Uji multikolineritas adalah untuk mengetahui ada tidaknya korelasi yang berarti antara masing-masing variabel bebas dalam model regresi. Metode untuk menguji ada tidaknya multikolinieritas dengan melihat nilai tolerance value dan variance inflation factor (VIF). Batas tolerance value adalah 0,10 dan batas VIF adalah 10, jika nilai tolerance value dibawah 0,10 dan nilai VIF diatas 10 maka terjadi multikolinieritas. Berdasarkan hasil tersebut dapat diketahui bahwa semua variabel independen yaitu penyuluhan (X1), motivasi (X2), Disiplin Kerja (X3) menunjukkan tidak terjadi multikolinieritas karena nilai dari tolerance value $>0,10$ dan nilai VIF kurang dari 10. 
- Uji Autokorelasi

Hasil uji autokorelasi menggunakan Run Test dengan bantuan program SPSS versi 12.0. for windows menunjukkan nilai $\mathrm{Z}$ sebesar 0,139 dengan tingkat signifikan sebesar 0,890 , di mana tingkat signifikansi lebih besar dari 0,005, ini berarti antara residual tidak terdapat korelasi.

- Uji Heteroskedastisitas

Hasil output uji Heteroskedastisitas menggunakan uji Glejser dengan bantuan program SPSS versi 12.0. for windows menunjukkan nilai signifikansi konstanta sebesar 0,291, penyuluhan (X1) sebesar 0,643, motivasi (X2) sebesar 0,9290, dan disiplin kerja (X3) sebesar 0,777 di mana $p>0,05$, ini berarti model regresi yang digunakan tidak terjadi heteroskedastisitas.

- Uji Normalitas

Pengujian normalitas dengan menggunakan uji Kolmogorov Smirnov, adalah sebagai berikut : Data hasil penelitian dari ke empat instrumen variabel Penyuluhan (X1), Motivasi (X2), Disiplin Kerja (X3) dan Produktivitas Petani (Y) yang diperoleh dari 51 orang responden melalui kuesioner, setelah dianalisis dengan menggunakan program SPSS versi 22.0 for windows ternyata menunjukkan nilai pola distribusi normal. Hal ini ditunjukkan oleh output perhitungan dengan menggunakan Kolmogorov Smirnov test (K-S). Hasil uji Kolmogorov Smirnov test (K-S) menunjukkan bahwa keempat variabel tersebut normal karena Unstandardized Residual Asymp. Sig $\quad(2$ tailed $)$ menunjukkan nilai signifikansi sebesar 0,860 di mana $\mathrm{p}>0,05$.

\section{Uji Koefisien Regresi Parsial (Uji t)}

Analisis ini bertujuan untuk menguji signifikansi pengaruh masing-masing variabel bebas yang mempengaruhi produktivitas kerja petani (Y) sehingga dapat diketahui bahwa pengaruh variabel bebas yaitu: penyuluhan (X1), motivasi (X2) dan disiplin kerja (X3), tidak hanya secara kebetulan mempengaruhi variabel terikat.

\section{Uji Koefisien Regresi Simultan (Uji F)}

Pengujian ini digunakan untuk membuktikan bahwa variabel penyuluhan (X1), motivasi (X2) dan disiplin kerja (X3) secara bersama-sama dalam mempengaruhi produktivitas kerja petani (Y). Berdasarkan hasil pengujian di atas dapat dijelaskan bahwa nilai Fhitung sebesar sebesar 
682,153 dengan taraf signifikansi 0,001 . Dengan demikian berarti bahwa dari ketiga variabel independen (penyuluhan, motivasi dan disiplin kerja) secara bersama-sama mempengaruhi variabel dependen (produktivitas kerja petani).

\section{Uji Koefisien Determinasi (Uji R2)}

Dalam penelitian ini untuk mengetahui seberapa kuat pengaruh variabel independen yaitu penyuluhan, motivasi dan disiplin kerja petani dalam mempengaruhi produktivitas kerja petani, yaitu dengan menggunkakan pengujian koefisien determinasi (R2). Nilai koefisien determinasi menunjukkan sebesar 0,976, artinya bahwa variabel independen (penyuluhan, motivasi dan disiplin kerja) mempengaruhi variabel dependen (produktivitas kerja) sebesar 97,6\% dan sisanya sebesar 2,4\% dipengaruhi oleh faktor yang lain diluar model.

\section{Implikasi}

Berdasarkan hasil pengujian hipotesis diketahui bahwa penyuluhan berpengaruh positif dan signifikan terhadap produktivitas kerja kelompok tani, hal ini jelas memberikan dampak yang positif terhadap produktivitas kerja kelompok tani di kampung Sekru, sehingga semakin baik pola/tipe penyuluhan yang diberikan maka akan memberikan implikasi yang nyata terhadap produktivitas kelompok tani tersebut sehingga meningkatkan hasil dan kualitas panen yang akhirnya pendapatan kelompok tani juga meningkat. Motivasi pengaruhnya positif tetapi tidak signifikan terhadap produktivitas kelompok tani, sehingga dapat disimpulkan bahwa peningkatan motivasi yang diberikan tidak memberikan implikasi yang signifikan terhadap produktivitas kelompok tani dikarenakan faktor penyuluhan yang diberikan lebih memberikan dampak yang nyata terhadap produktivitas kelompok tani. Disiplin kerja pengaruhnya positif dan signifikan terhadap produktivitas kelompok tani sehingga dapat disimpulkan bahwa disiplin kerja petani sangat mempengaruhi terhadap produktivitas kelompok tani di kampung Sekru, karena dengan disiplin kerja inilah petani tahu, mampu dan mau melaksanakan pekerjaannya sesuai dengan ilmu yang didapat dari penyuluhan. Berdasarkan implikasi yang didapat sebagai akibat dari diterapkanya penyuluhan, motivasi dan disiplin kerja kelompok tani maka secara otomatis memberikan implikasi terhadap produktivitas kelompok tani di kampung Sekru yang pada akhirnya meningkatkan pendapatan petani.

\section{KESIMPULAN DAN SARAN}

Dari pengumpulan sampai dengan analisis data penelitian, diperoleh kesimpulan sebagai berikut :

a. Hasil analisis regresi linier berganda diperoleh nilai konstanta (a) sebesar 
1,428 dan koefisien variabel $\mathrm{X}_{1}\left(\mathrm{~b}_{1}\right)$ sebesar 0,061 , koefisien variabel $X_{2}\left(b_{2}\right)$ sebesar 0,011 , koefisien variabel $\mathrm{X}_{3}\left(\mathrm{~b}_{3}\right)$ sebesar 0,982 dengan demikian maka persamaan regresinya adalah:

$$
\begin{aligned}
& Y=-1,428+0,061 X_{1}+0,011 X_{2}+ \\
& 0,982 X_{3}
\end{aligned}
$$

b. Hasil uji variabel $\mathrm{X}_{1}$ diperoleh nilai thitung sebesar 2,727 dengan signifikansi sebesar 0,009 yang berarti harga $t_{\text {hitung }}$ sebesar 2,727 signifikan pada $\alpha=5 \%$. Dengan demikian hipotesis yang menyatakan 'ada pengaruh antara penyuluhan terhadap produktivitas kerja petani' terbukti kebenarannya dan dapat diterima.

c. Hasil uji variabel $\mathrm{X}_{2}$ diperoleh nilai $\mathrm{t}_{\text {hitung }}$ sebesar 0,488 dengan nilai signifikansi sebesar 0,628 yang berarti nilai thitung sebesar 0,488 tidak signifikan pada $\alpha=$ $5 \%$, maka disimpulkan bahwa hipotesis yang menyatakan 'ada pengaruh motivasi kerja petani terhadap produktivitas kerja petani' tidak terbukti kebenarannya dan tidak dapat diterima.

d. Hasil uji variabel $\mathrm{X}_{3}$ diperoleh nilai $\mathrm{t}_{\text {hitung }}$ sebesar 38,401 dengan nilai signifikansi sebesar 0,001 yang berarti nilai thitung sebesar 38,401 signifikan pada $\alpha=5 \%$, maka disimpulkan bahwa hipotesis yang menyatakan 'ada pengaruh disiplin kerja petani terhadap produktivitas kerja petani' terbukti kebenarannya dan dapat diterima. e. Hasil analisis regresi simultan diketahui bahwa nilai $\mathrm{F}$ hitung adalah 682,153 dengan signifikansi sebesar 0,001 . Karena signifikansi kurang dari 0,05. maka harga $F_{\text {hitung }}$ sebesar 682,153 signifikan pada $\alpha=5 \%$.

f. Hasil perhitungan didapatkan nilai $R$ Square sebesar 0,978 yang berarti bahwa variasi independen yaitu gaya kerja manajerial, komunikasi interpersonal dan motivasi dapat menjelaskan sebesar $97,8 \%$ terhadap variasi variabel dependen yaitu prestasi kerja. Sedangkan sisanya sebesar 2,2\% dijelaskan oleh variabel diluar model penelitian.

g. Hasil uji variabel $\mathrm{X}_{1}$, nilai $\mathrm{t}_{\text {hitung }} 2,272$ dengan harga signifikansi sebesar 0,009 berarti $t_{\text {hitung }}$ sebesar 2,272 signifikan pada $\alpha=5 \%$. Hasil uji variabel X2, nilai $t_{\text {hitung }}$ sebesar 0,488 dengan nilai signifikansi sebesar 0,628 berarti nilai $\mathrm{t}_{\text {hitung }}$ sebesar 0,488 tidak signifikan pada $\alpha=5 \%$.

h. Hasil uji variabel $\mathrm{X}_{3}$, nilai thitung sebesar 38,401 dengan nilai signifikansi sebesar 0,001 berarti nilai $t_{\text {hitung }}$ sebesar 38,401 signifikan pada $\alpha=5 \%$. Dengan demikian hipotesis yang menyatakan bahwa pengaruh variabel disiplin kerja petani lebih dominan berpengaruh terhadap produktivitas kerja terbukti kebenarannya. 


\section{Saran}

Saran yang dapat diberikan adalah agar para penyuluh dapat mempertahankan metode dalam melaksanakan penyuluhan sesuai dengan yang telah terlaksana saat ini, dengan menggunakan bahasa yang lugas atau yang mudah dipahami oleh para petani kebun, agar para petani dengan mudah dapat memahami dan mengadaptasi metode bercocok tanam yang diajarkan. Khusus untuk komoditi pala, penyuluhan dan pendampingan sebaiknya dititik beratkan kepada para petani kebun yang melakukan peremajaan sejak awal, bahkan mulai masa pembibitan. Para petani pala juga sebaiknya diberikan pemahaman tentang berapa lama tanaman pala dapat memberikan hasil optimal, sehingga mereka siap melakukan peremajaan terutama atas tanaman pala yang telah berusia tua atau terkena penyakit.

\section{REFERENSI}

Burbank, Luther. (1997). Practical Orchard Plans and Methods : How to Begin and Carry on the Work. England. The Minerva Group.

Djarwanto, P. S., \& Subagyo, P. (1996). Statistik Induktif. Yogyakarta: BPFE..

Indonesia, K. B. B. (2005). Jakarta: Balai Pustaka.

Mosher, A. T. (1987). Menggerakkan dan membangun pertanian. Saluran $S$. Krisnandhi dan Bahrin Samad. Cv. Jasaguna, Jakarta.

Nicko, P. P. (2013). Pengaruh Kepemimpinan, Motivasi,
Lingkungan Kerja, dan Disiplin Kerja terhadap Kinerja Karyawan pada PT. Indonesia Power Semarang. Skripsi, Fakultas Ekonomi \& Bisnis.

Priyatno, D. (2008). Mandiri belajar SPSS. Yogyakarta: Mediakom.

Sarwono, J., Arikunto, M., \& Arikunto, M. S. (2006). Metode Penelitian. Kuantitatif Kualitatif.

Savill, P., Evans, J., Auclair, D., \& Falck, J. (1997). Plantation silviculture in Europe. Oxford University Press, UK.

Sedjo, R. A., \& Botkin, D. (1997). Using foret plantations to spare natural forests. Environment: Science and Policy for Sustainable Development, 39(10), 14-30.

Sugiyono, P. Dr. (2010). Metode Penelitian Kuantitatif, Kualitatif, dan $R \& D$. Bandung: CV Alfabeta.

Supranto, J. (2000). Teknik sampling untuk survei dan eksperimen. Jakarta: Rineka Cipta.

Taufiq, E., Suharman, H., Zarkasyi, M. W., \& Sueb, M. The Effects of Company Size, Corporate Strategy, Implementation of Environmental Management System (EMS) on the Application of Environmental Management Accounting and its Impact on Corporate Innovation.

Thompson, E. T. (1975). Plantation societies, race relations, and the South: the regimentation of populations: selected papers of Edgar T. Thompson. Books on Demand.

Wexley, K. N., \& Yukl, G. A. (1984). Organizational behavior and personnel psychology. Richard D. Irwin.

Wibowo, N. (2000). Analisis Budaya Perusahaan Dan Pengaruhnya Terhadap Kinerja Karyawan Di PT. Pura Barutama Kudus (Doctoral dissertation, Program Pascasarjana Universitas Diponegoro). 
